\title{
FECUNDITY OF BIOMPHALARIA STRAMINEA AND B. GLABRATA IN THE LABORATORY: A TWELVE-MONTH COMPARATIVE STUDY
}

\author{
B. ROZEMBERG; L. REY \& O. S. PIEAI*
}

Departamento de Ciências Biológicas, Escola Nacional de Saúde Pública, "Departamento de Biologia,
Instituto Oswaldo Cruz, Av. Brasil 4365, $21045-900$ Rio de Janeiro, RJ, Brasil

In the present comparative study a Biomphalaria straminea sample from Picos (Piauí) showed expressive advantages related to fecundity over $a$ B. glabrata sample from Belo Horizonte (Minas Gerais) such as: higher egg-mass production in 10 out of 12 months of study; higher egg production in all months of study; higher egg per egg-mass ratio in 11 out of 12 months of study; $66 \%$ of the egg-masses containing more than 20 eggs while in B. glabrata $70 \%$ of the egg-masses showed less than 20 eggs; three times less empty egg capsules than B. glabrata; attaining maximum fecundity in half the time required by B. glabrata. Mortality however was higher and sooner in B. straminea, suggesting higher semelparity in this species than in B. glabrata, a possibility that requires confirmation through long-term studies with other samples of both species. This first finding of a B. straminea sample more fecund than B. glabrata is discussed in relation to other data from the literature, and some recommendations are made on the quantification of fecundity of planorbid snails.

Key words: Biomphalaria straminea-Biomphalaria glabrala - fecundity

Occupying the largest geographical area and ranking the second in importance as Schistosoma mansoni host, Biomphalaria straminea is the least known species to be controlled in Brazil. In the past ten years most studies related to the species reported its identification in new biotopes, thus pointing to the increasing spread of the species'geographical domains. However only few studies were concerned with a sound knowledge on its ecology and bionomy. Besides enlarging the scope of control measures, the sound knowledge on $B$. straminea acquired new importance with the evidence of its dominance in areas formerly occupied by $B$. glabrata. The displacement of this last species by $B$. straminea was observed in Pernambuco (Barbosa, 1973), Minas Gerais (Paraense, 1986), and Martinique (Guyard \& Pointier, 1979).

The loss of $B$. glabrata populational balance due to the introduction of $B$. straminea is attributed to such factors as: lower susceptibility of $B$. straminea to $S$. mansoni infection; $B$. straminea higher resistence to dessication (Paraense, 1977; Barbosa, 1985); B. straminea higher

This study is part of the M. Sc. Thesis of the first author. fecundity rates when mixed with $B$. glabrata under crowding conditions (Michelson \& Dubois, 1979), as well as higher dispersion capability and vagility (Michelson \& Dubois, 1979; Barbosa et al., 1984). B. straminea high locomotion have already been reported in a previous study (Schall et al., 1986) where the species showed significantly higher ratios than $B$. glabrata and B. tenaghophila (Schall et al., 1984).

In view of the increasing and quickly expansion of $B$. straminea in different biotopes, and due to its high populational density in natural conditions, one can suppose that the species is extremely prolific. In the present study we tried to verify if this feature could be added to the above list of factors, thus favouring $B$. straminea in relation to $B$. glabrata. However, the few studies comparing the fecundity of the two species invariably assigned superiority to $B$. glabrata (Jansen, 1944; Penido et al., 1951; Andrade et al., 1974; Michelson \& Dubois, 1979) and that this is a current idea among medical malacologists. Given that the above-mentioned studies are of short-term nature, the present study offers a more detailed, long-term comparison between unmixed populations of the two species. 


\section{MATERIALS AND METHODS}

Snail samples used were $B$. straminea originating from Picos (Piaui, northeastern Brazil) and $B$. glabrata from Belo Horizonte (Minas Gerais, southeastern Brazil) provided by the Department of Malacology of the Instituto Oswaldo Cruz, where the colonies had been laboratory-reared for several generations. The snails used were reared from the embryo stage and fecundity quantification started one month after the beginning of their egg-laying activity. The total sample included thirty specimens of each species divided into groups of six per experimental container. Containers with 3.2 liters of dechlorinated tap-water served as medium. The water was renewed bimonthly and the substratum consisting of earth, calcium carbonate and oyster powder (in the proportion of 10:1.5:2 respectively, according to Paraense \& Corrêa, 1988) was renewed halfyearly. The snails were fed ad libitum with fresh lettuce and the unconsumed surplus was renoved the day after to avoid rottenness. The egg-masses were counted four to five times a week when the minimum and maximum air temperatures as well as the water temperature were recorded. The confrontation between temperature and fecundity variations was presented elsewhere (Rozemberg, 1989). Snails found dead or in anhydrobiosis were replaced by specimens of the same diameter and origin reared apart for this purpose. The differences in fecundity between months and between species were compared using the bilateral statistical test of Willcoxon (Siegel, 1956).

\section{RESULTS}

Table I shows the mean rate and standard deviation of the number of egg-masses laid by $B$. glabrata and B. straminea samples in each month.

The statistical analysis pointed to a highly significant superiority of $B$. straminea in the whole year (Fig. 1). The month by month analysis based on raw data also revealed a highly significant superiority of $B$. straminea fecundity rates in 10 out of 12 months of study. With regard to egg productivity, besides being significantly higher in all months of study, the superiority of $B$. straminea over $B$. glabrata was much more evident than that recorded for the production of egg-masses (Fig. 2). Superiority conversion was found in no data collection performed everyday for a 9 month-period. The average number of eggs per egg-mass for $B$. straminea was noticeably higher than for $B$. glabrata in all months, except for April (Fig. 3 ). The monthly average numbers for $B$. glabrata are very close to each other, ranging from 10 to 13.7 eggs per egg-mass, except for November, December and January. For $B$. straminea on the other hand these average numbers show a greater variation, ranging from 10.2 to 30.5 eggs per egg-mass.

\section{TABLE I}

Number of egg-masses and eggs per snail, and eggs per egg-mass (mean standard deviation) layed by Biomphalaria glahrata and $B$. stramined samples throughout one year, in laboratory

\begin{tabular}{|c|c|c|c|c|c|c|}
\hline \multirow{2}{*}{$\begin{array}{l}\text { Months } \\
\text { (No. of } \\
\text { observ.) }\end{array}$} & \multicolumn{2}{|c|}{ Egg-masses per snail } & \multicolumn{2}{|c|}{ tggs per snail } & \multicolumn{2}{|c|}{ Eggs per cgg-mass } \\
\hline & B. glahrata & B. straminea & B. glabrata & B. straminea & B. glabrata & B. straminea \\
\hline Aug. (18) & $0.61 \pm 0.22$ & $1.29 \pm 0.44$ & $6.19 \pm 2.65$ & $29.73 \pm 11.5$ & $9.92 \pm 1.47$ & $21.91 \pm 3.16$ \\
\hline Scp. (18) & $1.36 \pm 0.31$ & $1.47 \pm 0.23$ & $17.60 \pm 4.67$ & $45.33 \pm 9.45$ & $12.49 \pm 1.51$ & $30.52 \pm 3.06$ \\
\hline Oct. (22) & $1.38 \pm 0.24$ & $1.35 \pm 0.27$ & $19.11 \pm 4.16$ & $39.40 \pm 8.10$ & $13.70 \pm 1.97$ & $29.44 \pm 2.24$ \\
\hline Nov. $(18)$ & $1.20 \pm 0.22$ & $1.25 \pm 0.37$ & $21.79 \pm 4.33$ & $34.34 \pm 11.0$ & $18.17 \pm 2.24$ & $27.04 \pm 2.47$ \\
\hline Dez. (15) & $0.76 \pm 023$ & $0.98 \pm 0.18$ & $14.30 \pm 5.08$ & $26.54 \pm 5.64$ & $18.28 \pm 2.38$ & $26.57 \pm 2.85$ \\
\hline Jan. (18) & $0.72 \pm 0.25$ & $0.92 \pm 0.23$ & $13.62 \pm 5.64$ & $24.13 \pm, 9.23$ & $17.05 \pm 2.03$ & $26.87 \pm 4.75$ \\
\hline Feb. (15) & $0.31 \pm 0.13$ & $0.87 \pm 0.20$ & $3.73 \pm 2.32$ & $20.44 \pm 6.31$ & $11.26 \pm 3.63$ & $23.44 \pm 6.45$ \\
\hline Маг. (17) & $0.31 \pm 0.11$ & $0.84 \pm 0.25$ & $3.78 \pm 1.70$ & $15.01 \pm 5.36$ & $11.70 \pm 2.77$ & $16.77 \pm 3.45$ \\
\hline Арг. (18) & $0.30 \pm 0.11$ & $0.63 \pm 0.30$ & $3.29 \pm 1.54$ & $7.42 \pm 4.48$ & $11.08 \pm 3.71$ & $10.24 \pm 3.77$ \\
\hline May (12) & $0.47 \pm 0.19$ & $0.78 \pm 0.28$ & $4.37 \pm 2.04$ & $12.76 \pm 3.94$ & $8.43 \pm 2.53$ & $15.98 \pm 2.49$ \\
\hline Jun. (12) & $0.43 \pm 0.10$ & $0.71 \pm 0.17$ & $5.24 \pm 1.67$ & $14.82 \pm 4.27$ & $11.69 \pm 3.41$ & $20.05 \pm 3.33$ \\
\hline Jul. (8) & $0.40 \pm 0.13$ & $0.75 \pm 0.08$ & $5.30 \pm 2.14$ & $16.59 \pm 1.56$ & $13.13 \pm 2.94$ & $21.43 \pm 2.14$ \\
\hline $10101+191)$ & $0.69 \pm 0.41$ & $0.99 \pm 0.28$ & $10.01 \pm 6.90$ & $23.88 \pm 11.56$ & $13.08 \pm 3.19$ & $22.45 \pm 6.14$ \\
\hline
\end{tabular}




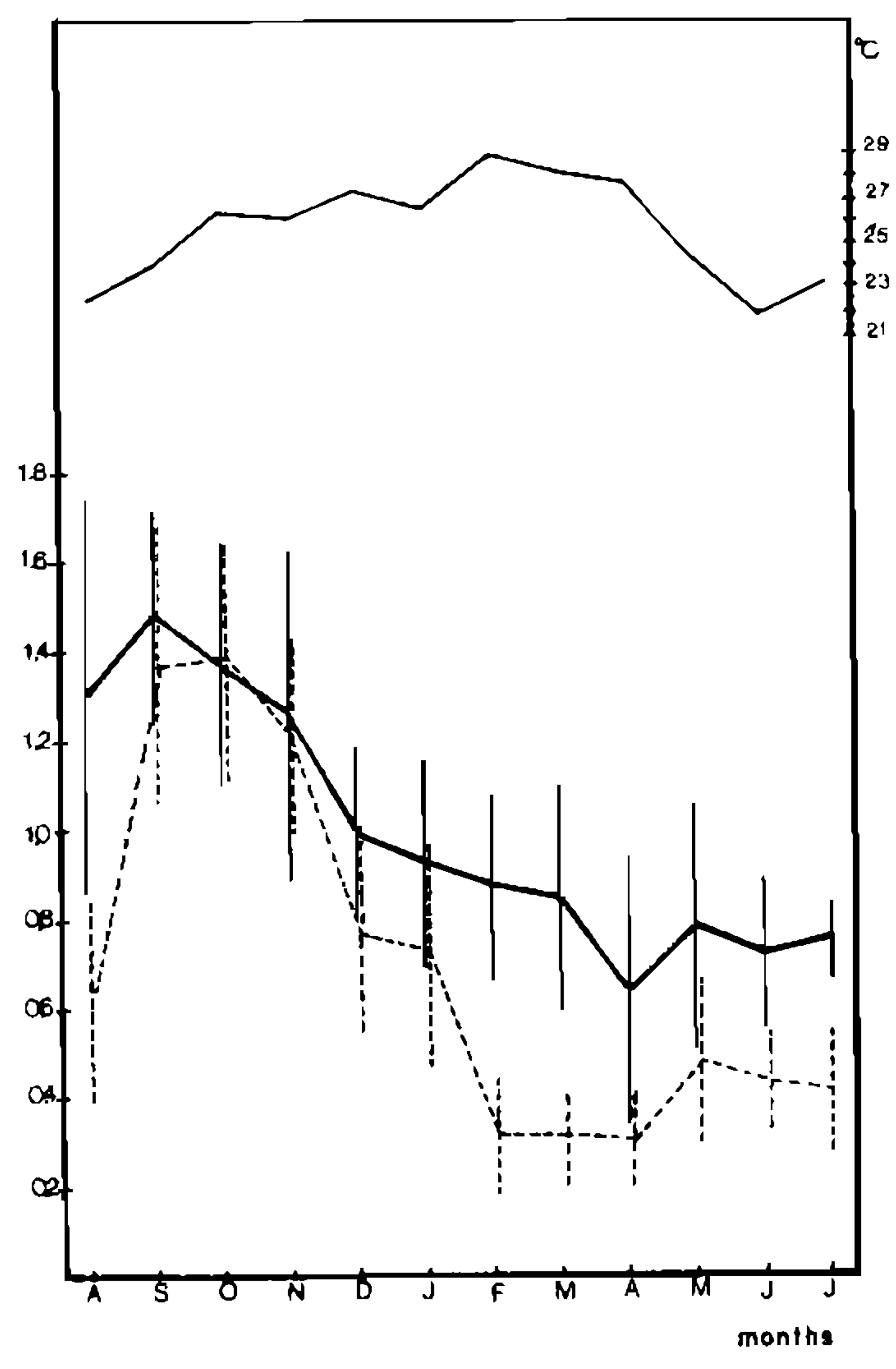

Fig. 1: monthly mean number of egg-masses per snail. Data obtained with 30 Biomphalaria straminea specimens (--) and 30 B. glabrala specimens (-.) throughout 12 months. The graph on the top shows monthly air temperatures.

Snail samples were also compared in terms of maximum number of eggs per egg-mass in each data collection (191 days), showing that in 6 out of 12 months of study $B$. straminea was significantly superior, while the opposite occurred just in a single month. The statistical comparison of the number of eggs in the largest egg-mass laid in each month pointed to a superiority of $B$. straminea in the whole year $(\mathrm{N}=12 ; \mathrm{T}=14 ; \mathrm{p}=0.05)$.

The comparison between minimum values of eggs per egg-masses in each data collection showed that in 4 out of 10 months the smallest egg-masses laid by $B$. straminea contained significantly more eggs than those laid by $B$. glabrata. The opposite occurred in a single month only. The comparison for the year as a whole could not be made because the smallest monthly value was invariably one for both snail samples.

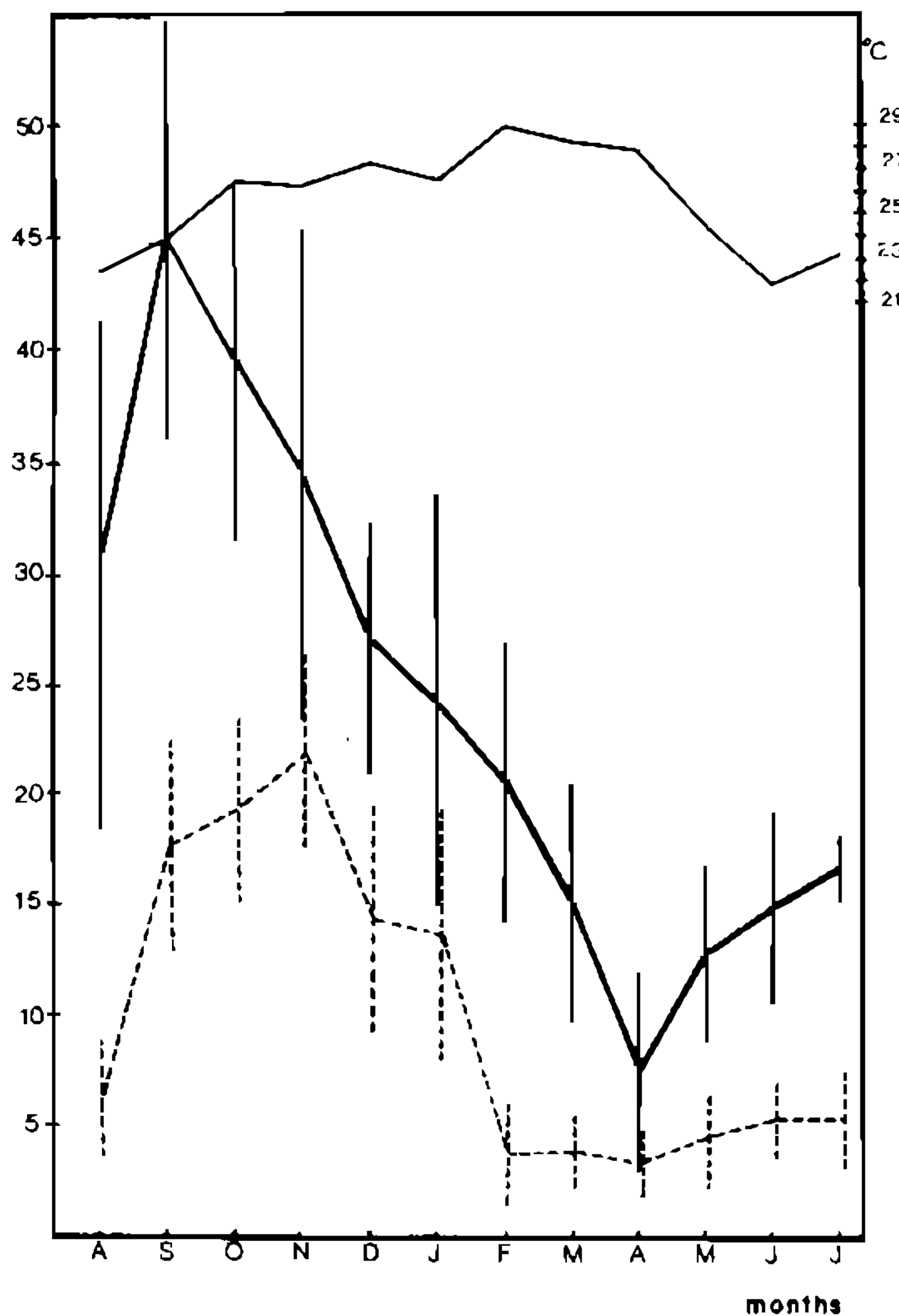

Fig. 2: monthly mean numbers of eggs per snails, (sec note on Fig. 1).

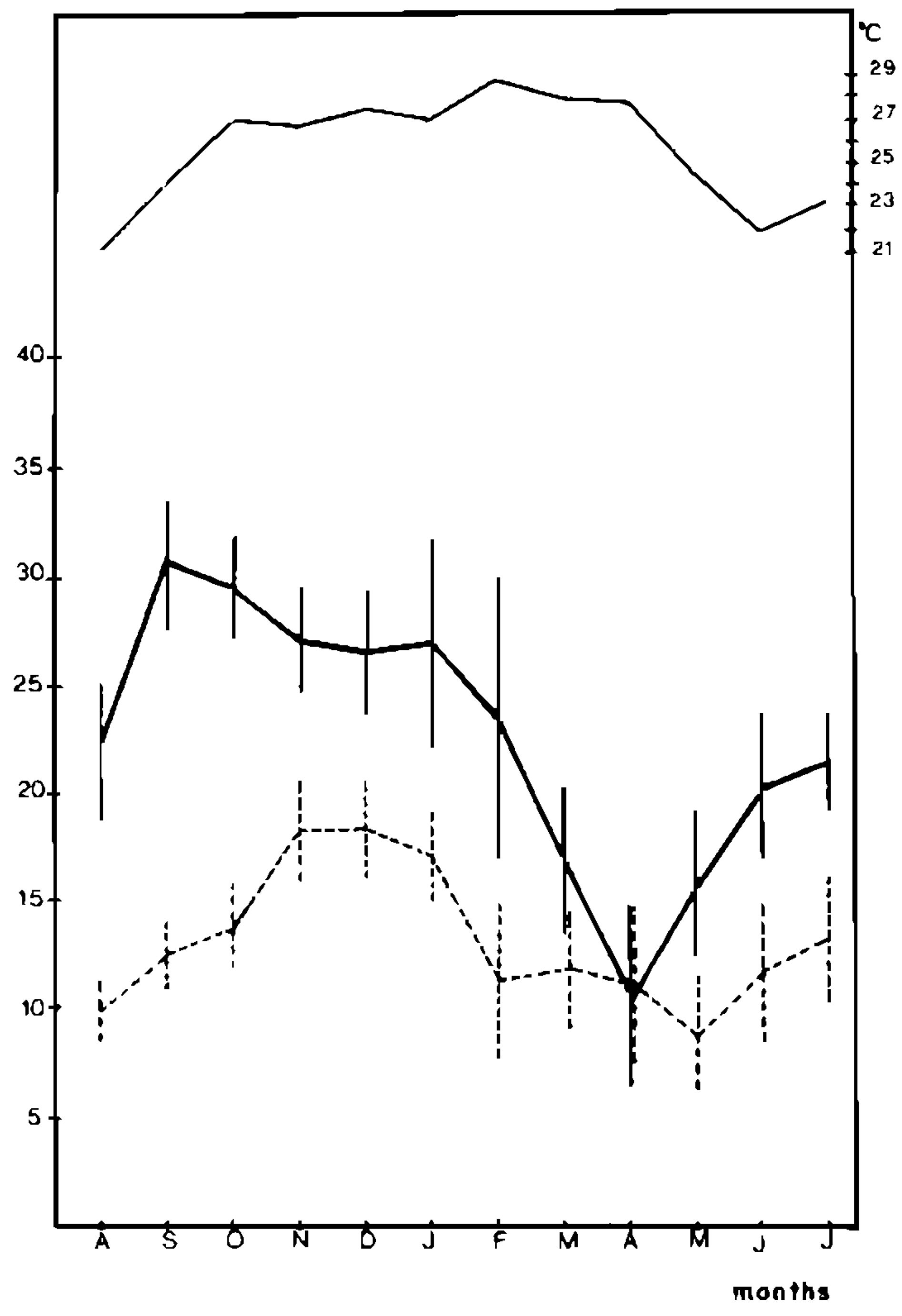

Fig. 3: monthly mean numbers of eggs per egg-mass, (see note on Fig. 1). 
In order to obtain more accurate information on the variability of the number of eggs per egg-masses, the egg-masses frequency was analysed according to classes of egg number.

\section{TABLE II}

Frequency of egg-masses in Biomphalaria straminea (BS) and B. glabrata (BG) according to classes of egg number

\begin{tabular}{crrrr}
\hline $\begin{array}{c}\text { Classes } \\
\text { of } \\
\text { egg number }\end{array}$ & \multicolumn{2}{c}{$\begin{array}{c}\text { Number of } \\
\text { egg-masses }\end{array}$} & \multicolumn{2}{c}{$\begin{array}{c}\text { Percentages } \\
\text { (\%) }\end{array}$} \\
\hline 0 to 9 & 1647 & 3029 & 16.3 & 41.6 \\
10 to 19 & 1734 & 2151 & 16.9 & 29.6 \\
20 to 29 & 3148 & 1358 & 30.7 & 18.7 \\
30 to 39 & 2494 & 499 & 24.3 & 6.9 \\
40 to 49 & 965 & 154 & 9.4 & 2.1 \\
50 to 59 & 211 & 59 & 2.1 & 0.8 \\
60 to 69 & 24 & 22 & 0.2 & 0.3 \\
70 to 79 & 2 & 3 & 0.02 & 0.04 \\
\hline Total & 10252 & 7275 & & \\
\hline
\end{tabular}
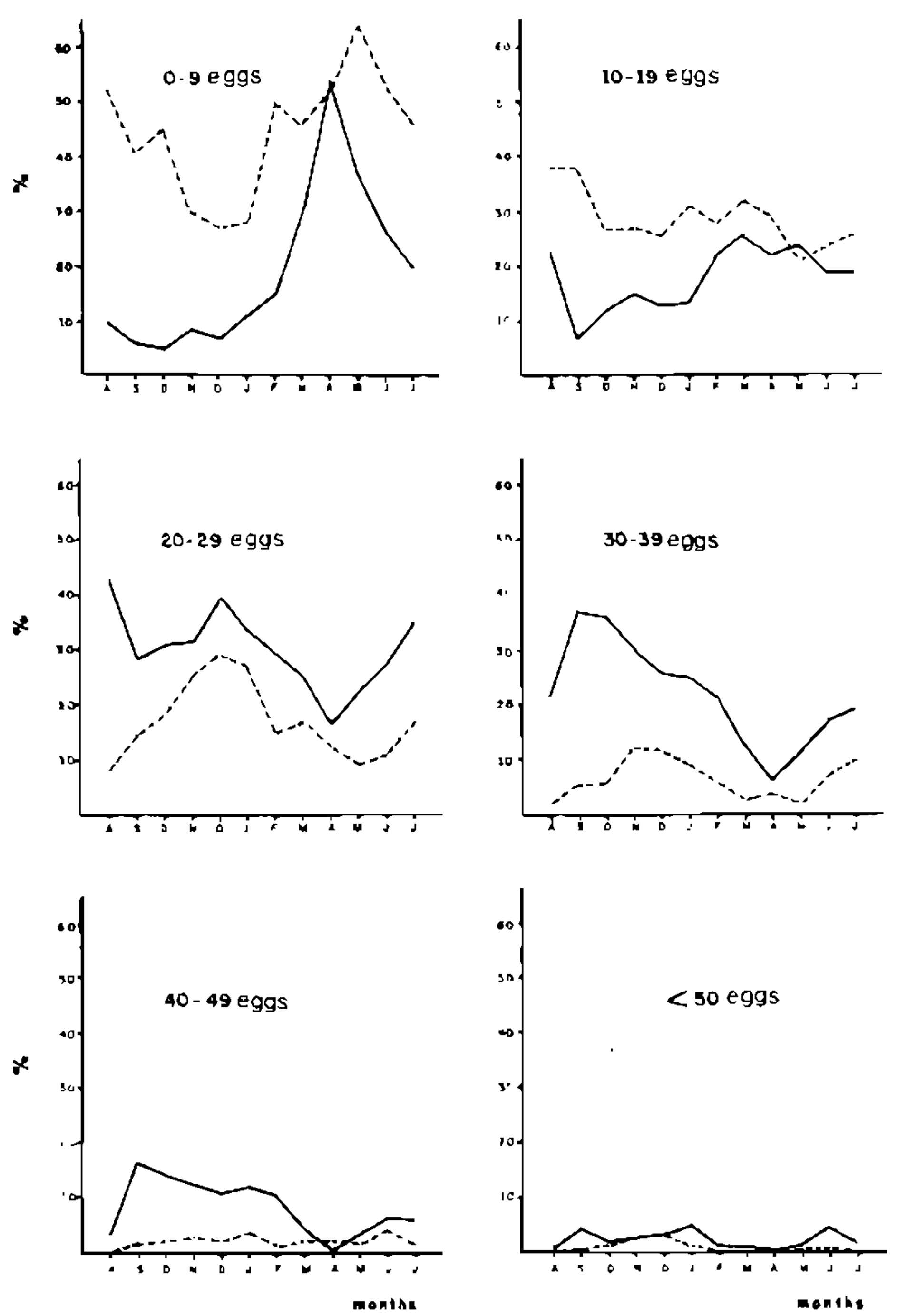

Figs 4-9: monthly frequency of egg-masses according to classes of egg number. Data obtained with $30 \mathrm{Biom}$ phalaria straminea specimens (-..---.), and $30 \mathrm{~B}$. glabrata specimens (- -).
Egg-masses with less than 20 eggs represented $71 \%$ of the total amount laid by $B$. glabrata but only $33 \%$ by $B$. straminea. The situation was quite the opposite in relation to egg-masses containing 20 to 40 eggs for they represented $55 \%$ in $B$. straminea and just $25 \%$ in B. glabrata. Larger egg-masses containing more than 40 eggs were also more common in B. straminea $(11 \%$ against only $3 \%$ in B. glabrata). It addition it should be emphasized that the distribution of $B$. straminea egg-masses according to classes was more balanced than that obtained with the $B$. glabrata sample. Figs 4 to 9 illustrate the evolution of thesc percentages throughouth the year.

The daily quantification of empty egg capsules laid throughout the study year (Table III) revealed that the deposition rate of empty capsules gradually increased with the aging of the two samples. Despite the phenomenon being confirmed by experts in personal communications, there is no reference to it in the available literature. The general computation showed that $B$. glabrata laid three times more empty capsules than $B$. straminea over the same period.

Snail mortality under experimental conditions is given in Fig. 10. The second and third months were the more difficult ones to $B$.

TABLE III

Comparative Fecundity of Biomphalaria straminea and B. glabrata: Monthly frequency of empty egg-capsules

\begin{tabular}{|c|c|c|c|c|}
\hline Month & $\begin{array}{c}\text { B. straminea } \\
\text { Empty } \\
\text { capsules/ } \\
\text { Total of } \\
\text { capsules }\end{array}$ & $\%$ & $\begin{array}{l}\text { B. glabrata } \\
\text { Empty } \\
\text { capsules/ } \\
\text { Total of } \\
\text { capsules }\end{array}$ & $\%$ \\
\hline August & $1 / 973$ & 0.1 & $0 / 455$ & 0 \\
\hline September & $1 / 1323$ & 0.08 & $1 / 1221$ & 0.08 \\
\hline October & $3 / 1257$ & 0.24 & $15 / 1286$ & 1.17 \\
\hline November & 4/ 1121 & 0.36 & $11 / 1077$ & 1.02 \\
\hline Wecember & 6/ 914 & 0.66 & $19 / 710$ & 2.68 \\
\hline lanuary & $8 / \quad 858$ & 0.93 & $41 / 672$ & 6.10 \\
\hline ஃ ஃ bruary & 11/ 730 & 1.51 & $20 / 261$ & 7.66 \\
\hline Murch & $17 / 785$ & 2.17 & $12 / 284$ & 4.23 \\
\hline April & $29 / 567$ & 5.12 & 29/ 272 & 10.66 \\
\hline May & $43 / 723$ & 5.95 & $100 / 441$ & 22.68 \\
\hline June & $13 / 641$ & 2.03 & $52 / 389$ & 13.37 \\
\hline July & 6) 381 & 1.58 & $31 / 209$ & 14.83 \\
\hline o otal & $142 / 10273$ & 1.38 & $331 / 7277$ & 4.55 \\
\hline
\end{tabular}




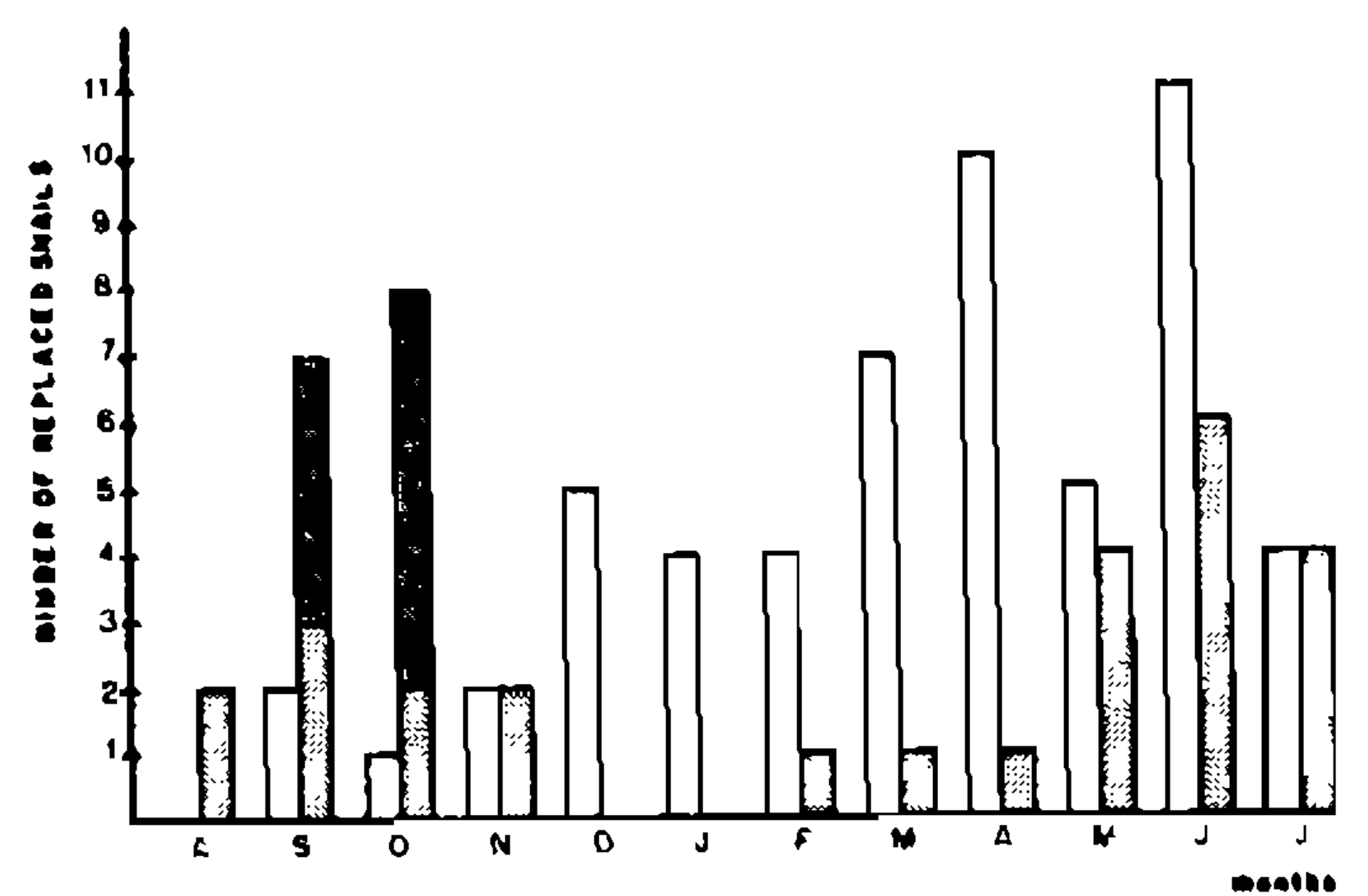

Fig. 10: snail mortality under experimental conditions. $\square$ B. straminea; $B$. glabrala; 1 anhydrobiosis.

\section{TABLE IV}

Monthly variation of water temperature and maximum and minimum air temperature

\begin{tabular}{lccl}
\hline & \multicolumn{3}{c}{ Air } \\
Months & Maximum & Minimum & Water \\
\hline August & 24.8 & 22 & 21.2 \\
September & 26.4 & 23.7 & 24.3 \\
October & 29.2 & 25.9 & 26.9 \\
November & 28.9 & 25.6 & 26.7 \\
December & 29.8 & 26.5 & 27.5 \\
January & 29.1 & 26 & 27 \\
February & 31.5 & 28.4 & 28.9 \\
March & 30.6 & 28 & 28.1 \\
April & 30.7 & 26.9 & 27.9 \\
May & 27.4 & 23.5 & 24.4 \\
June & 24.6 & 21.2 & 22 \\
July & 26 & 22.8 & 23.2 \\
\hline
\end{tabular}

glabrata, while $B$. straminea was fairly well acclimated to the experimental environment in this early phase of the study. From the eighth month forward, particularly in the ninth and tenth month, $B$. straminea sample showed a high mortality, while in $B$. glabrata it only became expressive from the tenth month forward.

\section{DISCUSSION}

There are many references to the great reproductive potential of $B$. straminea in field conditions. Malacologists agree that this species, in maintaining schistosomiasis cycle in extensive areas, counterbalances its low susceptibility to $S$. mansoni infection with an extraordinary proliferation capability. In laboratory conditions however this high fecundity of $B$. straminea has never been confirmed before. From Jansen's observations (1944) to more recent studies, $B$. glabrata is referred to as the more prolific of the two species. The present results therefore constitute the first laboratory record of higher fecundity of $B$. straminea compared to B. glabrata.

It is important to emphasize that the present study, like any other study using a single population sample of each species, does not provide for generalizations because of the high variability among populations of a species, particularly if we deal with pulmonate snails. As stated by Meier-Brook (1986), in this taxa there has been very little adaptative radiation in the geological past in comparison with the one that has taken place in prosobranch gastropods. As a result many pulmonate species have maintained a high flexibility to environmental changes leading to high variation between species populations.

Egg laying frequency - B. glabrata mean rate for the whole year $(0.69$ egg-masses per snail per day) is compatible with data from other studies: Scherrer et al. (1976) found 0.69 in one of their study samples; Magalhães \& Carvalho (1969), in a thirty days study, found 0.64; the same ratio was obtained by Kawazoe (1980) in a one year study; Paulini \& Camey (1964) found 0.7 egg-masses per snail per day in the least prolific population of their study. The high variations of the present $B$. glabrata sample throughout the year allowed the finding of ratios compatible either with the most or with the least prolific samples reported in the literature. Hence, from February to April we obtained the low ratio of 0.3 , identically to that obtained by Michelson (1961) and to the value range reported by Rey (1956), 0.19 to 0.42 egg-masses per snail per day. However, in months of higher fecundity (Table I) we recorded 1.36 and 1.38 egg-masses per snail per day, a result compatible with that of Liard et al. (apud Scherrer et al. 1976) and Pauliny \& Camey (1964), both indicating 0.93. Given this high variation in the egg-laying frequency of a single sample under study, it is clear that extensive long-term studies are required before imputing any feature as inherent to a given population.

For $B$. straminea the mean rate obtained, 0.99 egg-masses per snail per day, is compatible with that reported by Lucena (1956), 1.29, both extremely higher than the 0.22 egg-masses per snail per day obtained by Andrade et al. (1973). 
Number of eggs per snail - The mean rate of 10 eggs per snail per day recorded for $B$. glabrata throughout the year is compatible with the results obtained by other authors: Michelson (1961), 8.96; Scherrer et al. (1976), 7.0 and 10.6; Coelho (1954), 12.3; and Andrade et al. (1974), 13.53. Higher ratios have been found by Szumlewicz (1958), 18.1; Chernin \& Michelson (1957a and b), 17 and 17.3; and $\mathrm{Mi}$ chelson \& Dubois (1979), 16.75 (this ratio was computed based on tables presented by the authors). Here again, if one considers the egg prodution of the present sample only during more fecund months of the year (September, 17.6; October, 19.1; and November, 21.8) the results would be comparable with the highest figures presented above. The only data that really diverge from all others available in the literature were those recorded by Scherrer et al. (1976), 41.6 and 40.5, surmounting all other observations made for $B$. glabrata.

Few data are available in the literature on B. straminea egg production. The mean rate obtained in the present study (23.88) is compatible with those obtained by Lucena (1956), 28.15; and Michelson \& Dubois (1979), 20.09 (the latter was calculated from tables presented by the authors). These three values however are much higher than the 2.3 eggs per snail per day reported by Andrade et al. (1973). If we consider that the last result was obtained by the authors during the winter (May to August), and taking into account the low temperatures recorded by them during these months, the low egg production rate is at least partly explained. Based on the present long-term observations (Table $I$ ) there was in fact a decrease of $B$. straminea egg productivity during these months (May to August) when air and water mean temperatures were lower than in the remaining months of the year. Only considering data collected from April to July, our mean rate falls to 12.9 eggs per snail, only half of the 23.88 obtained for the entire year.

In the comparison of egg productivity between $B$. glabrata and $B$. straminea, as previously stated, the few studies available give superiority to the former, though none of these studies present enough data to support this idea. Andrade et al. (1974) compared B. straminea fecundity during winter with $B$. glabrata fecundity during spring of the subsequent year, attributing superiority to the latter. This species however was probably favoured by the higher temperatures recorded by the authors in comparison with those recorded during tests with $B$. straminea. Once again this possibility can be confirmed using the present data: considering the fecundity of $B$. glabrata just in spring months our mean rate that was 10 eggs per snail per day rises to 18.2. Michelson \& Dubois (1979) also stated, for the control colonies of their study, that $B$. glabata produced more eggs than $B$. straminea, even though the summing up of data published by these authors does not confirm this statement.

Average number of eggs per egg-mass The first study in the literature comparing this parameter for the two species dates from 1944. At that time, Jansen found a mean rate of 12 eggs per egg-mass for $B$. straminea, while for $B$. glabrata he found 45 . The results obtained by Penido et al. (1951) indicated 13.2 and 24.5 eggs/egg-mass respectively. Both study results differ significantly from those obtained by us in the present study. This type of comparison is however of limited worth, not only because of the high variability among species populations, diferences in snail rearing, and difficulties in species characterization at that time, but also due to the fact that those snails were brough directly from field to be studied. According to Scherrer et al. (1976), Barbosa \& Silva (1951) and Freitas (1959) have also obtained high values for $B$. glabrata specimens brought directly from field (47 and 44 eggs per egg-mass respectively).

In laboratory B. glabrata eggs/egg-mass averages show great variations. Pereira \& Deslandes (1954 apud Scherrer et al. 1976) found 36.9 and 61; Freitas (1973 apud Scherrer et al. 1976), 34.9, 39.9 and 62.1; Scherrer et al. (1976), 45.1 and 44.5 and, with their less prolific population, 19.2 and 14.6 eggs/eggmass. Brumpt (1941) obtained 23.3; Coelho (1954), 22; Rey (1956), 10.23 and 21.3; Chernin \& Michelson (1957a, b), 15.8 and 17.1; Szumlewicz (1958), 10.1, 14.7 to 15.1 and 18.2 to 24.5; Michelson (1961), 13.5; Magalhães \& Carvalho (1969), 21.34; Pimentel (1957), 10.6 and Michelson \& Dubois (1979), 21.4 eggs/ egg-mass.

Our global mean rate (13.8 eggs/egg-mass) is then among the lower rates but it is still higher than many others. Except for November, December and January (with higher mean rates) the other months showed very similar mean rates. Although it is impossible to characterize species using this parameter, we sug- 
gest, based on the similarity among mean rates throughout the year, that this parameter can be useful for the characterization of $B$. glabrata populations. It must be clear however that this is only possible when a high number of measurements is involved, as in the case of the present study. In this case, it seems to be possible to know the fecundity potential of a $B$. glabrata population for specific rearing conditions adopted.

For the $B$. straminea sample our general mean rate for the year was 22.44 eggs per eggmass. Similarly high results have been obtained by Michelson \& Dubois (1979), 25.07 (calculated based on data presented by the authors), and by Lucena (1956) after six months of study, 22.10 eggs per egg-mass.

Except for the two above-mentioned studies and for the present work, the few other studies quantifying the fecundity of $B$. straminea show surprisingly low data. Jansen (1944) reports 12 eggs per egg-mass, but based on 50 egg-masses only; Andrade et al. (1973) in cold months obtained 11.4; and Penido et al. (1951), 13.2 eggs per egg-mass. Coincidently these last authors have also studied the species during the part of the year that includes the colder months in Brazil (March to July). Although they did not provide temperature data, the period chosen for the study may be at least in part responsible for the low fecundity observed, as we suggested for the results of Andrade et al. (1973) and confirmed by our own observations (Table I).

At any rate it should be stressed that we were dealing with a prolific sample of $B$. straminea. The possibility of a genetic drift due to sample collection and laboratory-rearing for manu gennerations is not excluded. Unfortunately the data available are not enough to infer whether the finding of such a prolific sample of $B$. straminea is common or rare within the species. According to Paraense (personal communication), who provided the sample, the Picos colony is remmarkably more fecund than other samples reared in his laboratory under identical conditions.

Maximum and minimum number of eggs per egg-mass in each data collection and in each month - This parameter proved to be useful for the comparison of snail fecundity since it confirmed the superiority of $B$. straminea in the general computation and in great part of the monthly analysis. The use of extreme values reduces the quantifying work and can be reliable if a great number of measurements is involved, as in the present study. Though minimum values provided few information, they attested the superiority of $B$. straminea in 4 out of 11 months in wich it actually occurred.

Egg-masses frequency according to classes of egg number - The high fecundity of $B$. straminea sample is related to a great productivity of eggs arranged in a relatively low number of capsules. Capsule production and egg production might therefore be disentailed processes, that react distinctly to stimuli. This possibility is reinforced by the decrease of the number of eggs due to the aging of snails, the number of capsules remaining the same, resulting in increasing numbers of empty capsules.

The production and laying of capsules may constitute a considerable investiment of resources (Calow, 1983). In this sense, the production of capsules with few or no eggs may represent a waste of material and energy that occurs much more regularly in the $B$. glabrata sample (Table III). On the other hand note should be given to the low cost of capsule per egg laid by $B$. straminea especially from September to December, when the production of capsules was fairly profitable in decendant production.

Biomphalaria straminea tendency to pack up more eggs per capsule showed a cyclical variation during the year, and this variation cannot be directly related to fecundity. Rey (1956) and Parent \& Lietar (1955) also observed seasonal cyclical variations in the mean number of eggs per capsule in planorbid snails. The first author could not detect the reasons for the phenomenon, but for Parent \& Lietar (1955) the increasing number of eggs per capsule was associated with the coming of the dry season. Calow (1983) also observed this relationship and formulated an interesting hypothesis to explain it. By studying a Limnaea peregra population this author observed that in lentic habitats where descendant survival chances were higher, the species were found packing a higher number of eggs per capsule than in seashore habitats where the snails were exposed to wave action. The proposed hypothesis is that capsule economy without implying losses for the next generation is 
practicable in calm waters. Reversely, where the environment exposes egg-masses to damage and destruction, the species distributes its eggs in greater number of capsules then leading to better survival changes. This hypothesis however requires experimental confirmation.

With regard to our $B$. straminea sample further observations might confirm the cyclical nature of eggs per capsule rates. Temperature may also be affecting this seasonal variation, although this hypothesis also requires a carefully controlled experiment.

Eggs per capsule variation related to snail size - The increasing number of eggs per capsule due to the growth of snails is related to the need for a complete development of the reproductive apparatus in order to achieve the maximum performance in the perpetuation of species. This could be easily detected in $B$. glabrata from the first to the fourth month of study. This directly proportional relationship between size and number of eggs per capsule was also observed in B. straminea, but only form the first to the second month of study (Figs 4 to 9). In this period the increase in the number of eggs per capsule was actually very expressive, achieving already in the second month 30.52 eggs per capsule, which was the maximum rate for $B$. straminea for the whole year. However this is not so surprising if we take into account that by this time. $B$. straminea specimens were achieving their definitive adult diameter (for the conditions adopted). Although growth curves were not studied, $B$. straminea sample growth ceased precociously when compared to $B$. glabrata. The latter, by investing part of its resources in growth and part in reproduction, took four to five months to achieve its maximum rate of eggs per eggmass.

Potential advantadges for $B$. straminea sample can thus be viewed, especially if the above possibilities are considered within a hypothetical situation of crowded mixed populations. In this case one may suggest the occurrence of a reproductive boom of $B$. straminea two months before $B$. glabrata could massively repopulate the habitat. When this occurs, the latter species would be restricted in terms of space and resources by the presence of a $B$. straminea population steadily established in the habitat and ready to present a new population increase potentially similar to the previous one, since the second generation's full productivity will be reached.

It should be noted that data on egg fertility, young specimen's development and mortality, and environmental resistence are not included in this hypothetical forecast since only data on egg and egg-mass productivity of the two samples are being considered. However, recent findings on $B$. pfeifferi under field conditions (Loreau \& Baluku, 1987) detected a strong correlation between " $r$ " parameter (intrinsic rate of natural increase) and egg density curves for the same period (a 4-year study). The authors point to the possibility of inferring " $r$ " based on a single factor: egg density. They emphasize that other studies are required to test the reliability of such correlation for other species and different environmental conditions.

Monthly frequency of empty egg-capsules - Paraense (1959) reported the presence of empty capsules as a result of the crossing of different $B$. glabrata populations. The more distant are the populations involved, the greater is the occurrence of empty capsules. Our study deals with a single population and shows the progressive increasing frequency of empty capsules throughout the year for both species. For B. glabrata it occurred more regularly and in a frequency always significantly higher than for $B$. straminea (about three times higher). Although we did not find any other reference to the phenomenon, it seems to be naturally related to snail aging. The decrease of gamete production as a result of aging was not promptly followed by the reduction in capsule production, thereby leading to a progressively higher frequency of empty capsules.

Snail mortality - Mortality was higher and sooner in B. straminea than in B. glabrata. One may suggest that semelparity (tendency to invest more in reproduction than in the maintenance of adults) is more marked in the former. This interesting issue deserves further investigations based on different rearing conditions and different populations of both species.

\section{ACKNOWLEDGEMENTS}

To Dr Fernando D. Ávila-Pires, Dr Lobato Paraense, Dr Lígia Corrêa and Dr Frederico S. Barbosa for their colaboration in several occasions. 


\section{REFERENCES}

ANDRADE, R. M. de; CARVALHO, O. S. \& PINTO ALVES, M. D. P., 1973. Alimentação e fecundidade de planorbídeos criados em laboratório. Il - Biomphalaria straminea (Dunker, 1848). Rev. Bras. Biol., 33: 119-126.

ANDRADE, R. M. de; CARVALHO, O. S. \& MENEZES, W. T., 1974. Alimentação e fecundidade de planorbídeos criados em laboratório. III - Biomphalaria glabrata (Say, 1818) (Pulmonata, Planorbidae). Rev. Bras. Malariol. Doenf̧as Trop., 26: 109-129.

BARBOSA, F. S., 1973. Possible competitive displacement and evidence of hybridization between two brazilian species of planorbid snails. Malacologia. 14: $401-408$.

BARBOSA, F. S., 1985. A Competição biológica como método alternativo para o controle dos transmissores da esquistossomose. Cad. Saúde Públ., I: 113-114.

BARBOSA, F. S.; PEREIRA DA COSTA, D. P. \& ARRUDA, F., 1984. Competitive interactions between species of freshwater snails. I - Laboratory studies. l. b. - Comparative studies of the dispersal and the vagility capabilities of Biomphalaria glabrata and Biomphalaria straminea. Mem. Inst. Oswaldo Cruz, 79: 163-167.

BRUMPT, E., 1941. Observations biologiques diverses concernant Planorbis (Australobis) glabralus, hôte intermediaire de Schistosoma mansoni. Ann. Parasitol. Hum. Comp.. 18: 9-45.

CALOW, P., 1983. Life-cycle patterns, p. 649-678. In W. D. Russel-Hunter - The Mollusca. wol. 6: Ecology. London, Academic Press.

CHERNIN, E. \& MICHELSON, E. H., 1957a. Studies on the biological control of schistosome-bearing snails. III - Effects of population density on growth and fecundity in Australorbis glabratus. An. J. Hyg., 65: $71-80$.

CHERNIN, E. \& MICHELSON, E. H., 1957b. Studies on the biological control of schistosome-bearing snails. IV - Further observations on the effects of crowding on growth and fecundity in Australorbis glabratus. An. J. Hyg., 65: $71-80$.

COELHO, M. V., 1954. Ação das formas larvárias de Schistosoma mansoni sobre a reprodução de Australorbis glabratus. Publ. Avulsas Inst. Aggeu Magathäes, 3: 39-54.

GUYARD, A. \& POINTIER, J. P., 1979. Faune malacologique dulciaquicole et vecteurs de la schistosomose intestinale en Martinique. Ann. Parasitol. Hum. Comp., 54: 193-205.

JANSEN, G., 1944. Sobre a validade de Australorbis centimetralis (Lutz, 1918). Nota prévia. Mem. Inst. Oswaldo Cruz, 40: 201-208.

KAWAZOE, U., 1980. Alguns aspectos da biologia de Biomphalaria glabrata (Say, 1818) e Biomphalaria tenagophila (d'Orbigny, 1835) (Pulmonata, Planorbidae). II - Focundidade e Fertilidade. Rev. Saúde Pública, São Paulo, 14: 65-87.

LOREAU, M. \& BALUKU, B., 1987. Population dynamics of the freshwater snail Biomphalaria pfeifferi in Eastern Zaire. J. Molluscan Stud., 53: 249-266.

LUCENA, D. T., 1956 - Resenha Sistemática dos Planorbideos Brasileiros. M. Sc. Thesis, Recife, Gráf. Edit. Recife S. A., 104 p.
MAGALHAES, L. A. \& CARVALHO, D. F., 1969. Estudo da postura de duas populaçōes de planorbideos. Rev. Soc. Bras. Med. Trop., 3: 245-247.

MEIER-BROOK, C., 1986. An ecological survey of freshwater mollusc introduction. Ninth Intermational Malacological Congress, Edinburgh, Scotland. Abstract: 52.

MICHELSON, E. H., 1961. The effects of temperature on growth and reproduction of Australorbis glabratus in the laboratory. Am. J. Hyg. 73: 63-74.

MICHELSON, E. H. \& DUBOIS, L., 1979. Competitive interactions between two snail hosts of Schistosoma mansoni: Laboratory studies on Biomphalaria glabrata and B. straminea. Rev. Inst. Med. Trop. Säo Paulo, 21: 246-253.

PARAENSE, W. L., 1959. One-sided reproductive isolation between geographically remote populations of a planorbid snail. Am. Nat., 93: 93-101.

PARAENSE, W. L., 1977 - Distribuiçāo geográfica dos vetores da schistosomose no nordeste do Brasil. In P. A. Machado, (coordenador), Painel Especial de Controle da Esquistossomose: 47-51. Apresentado na VI Conferência Nacional de Saúde, Brasília.

PARAENSE, W. L., 1986. Distribuiçāo dos caramujos no Brasil, p. 117-126. In Academia Mineira de Medicina, Modernos conhecimentos sobre esquistossomose mansónica. Belo Horizonte, MG, vol. 14 (suppl. dos anais de 1983 e 1984).

PARAENSE, W. L. \& CORREA, L. R, 1988. Selffertilization in freshwater snail Helisoma duryi and Helisoma trivolvis. Mem. Inst. Oswaldo Cruz, 83: 405-409.

PARENT, M. \& LIETAR, J., 1955. Contribuitiun à l'etude de la biologie des mollusques à Jadotville. Ann. Soc. Belge Med. Trop., 35: 59-68.

PAULINY, E \& CAMEY, T., 1964. Observaçōes sobre a biologia de Australorbis glabratus. II - Influência da temperatura do ambiente sobre a frequência de postura. Rev. Bras. Malariol. Doenças Trop., 16: 499-504.

PENIDO, H. M.; PINTO, D. B. \& DESLANDES, N., 1951. Observações sobre as posturas e tempo de evolução de duas espécies de caramujo encontrados no Vale do Rio Doce. Rev. Serv. Espec. Saúde Pública, 4: 407-412.

PIMENTEL, D., 1957. Life history of Australorbis glabratus, the intermediate snail host of Schistosoma mansoni in Puerto Rico. Ecology. 38: 576-580.

REY, L., 1956. Contribuição para o conhecimento da morfologia, biologia e ecologia dos planorbideos brasileiros transmissores da esquistossomose - sua importancia em epidemiologia. PhD Thesis. Fac. Med. Univ. São Paulo, São Paulo, 217 p.

ROZEMBERG, B., 1989. Fecundidade comparada de Biomphalaria straminea e B. glabrata em laboratório, no decurso de um ano. M. Sc. Thesis, Instituto Oswaldo Cruz, Rio de Janeiro, 165 p.

SCHALL, V. T.; JURBERG, P. \& FERREIRA, S. R, 1984. Estudo Comparativo do efeito da luz sobre o comportamento das espécies Biomphalaria glabrata, B. lenagophila e B. straminea (Molusca, Gastropoda, Planorbidae). XI Congresso de Zoologia. Resumos: $4 \mid-42$.

SCHALL, V. T.; JURBERG, P. \& ROZEMBERG, B., 1986. Orientation of the snail Biomphalaria 
straminea (Dunker, 1848) in response to light in a situation of selection. Mem. Inst. Oswaldo Cruz, 81: 255-263.

SCHERRER, J. F.; CHQUILOFF, M. A. de G. \& FREITAS, J. R. de, 1976. Estudo Comparativo da reprodução em quatro variedades genéticas de Biom- phalaria glabrala (Say, 1818). I - Fecundidade. Rev. Inst. Med. Trop. São Paulo, 18: 315.321.

SZUMLEWICZ, A. P., 1958. Studies on the biology of Australorbis glabratus, a schistosome-bearing brazilian snail. Rev. Bras. Malariol. Doenças Trop., 10: 459-529. 